\title{
First record of the invasive Hemidactylus mabouia (Moreau de Jonnès, 1818) (Squamata, Gekkonidae), in the dry Chaco, Argentina
}

\author{
Pablo Javier Torres, Orlando Escalante, Darío Cardozo
}

Laboratorio de Genética Evolutiva, Instituto de Biología Subtropical (IBS, UNaM-CONICET), Feliz de Azara 1552, Posadas, CP 3300, Misiones, Argentina.

Corresponding author: Darío Cardozo, darcardz@gmail.com

\begin{abstract}
The invasive Hemidactylus mabouia (Moreau de Jonnès, 1818) is one of the most widespread introduced species of reptiles, being present in the New World at least 500 years ago. In this work, we report for the first time, the presence of the invasive gecko H. mabouia in the dry Chaco, a biogeographic region included in the Gran Chaco Sudamericano. We collected 3 individuals in an urban zone at Las Lomitas, Patiño department, Formosa Province, Argentina. This new record extends the distribution range of this introduced species by nearly $300 \mathrm{~km}$ (in a straight line) from Formosa city, the nearest point previously reported.
\end{abstract}

Key words

Introduced species; Hemidactylus; gecko; biogeographic region.

Academic editor: Raúl Maneyro | Received 4 April 2018 | Accepted 10 July 2018 | Published 3 August 2018

Citation: Torres PJ, Escalante O, Cardozo D (2018) First record of the invasive Hemidactylus mabouia (Moreau de Jonnès, 1818) (Squamata, Gekkonidae), in the dry Chaco, Argentina. Check List 14 (4): 633-636. https://doi.org/10.15560/14.4.633

\section{Introduction}

The invasive Hemidactylus mabouia is one of the most widespread introduced species of reptiles (Hughes et al. 2015). It inhabits in many countries of Africa (including several Seychelles islands), the Caribbean; in the state of Florida (USA), on Madeira (Portugal), Central America (Costa Rica, Honduras, Mexico, and Panama), and South America (Argentina, Bolivia, Brazil, Colombia, Ecuador, French Guiana, Guyana, Paraguay, Peru, Suriname, Venezuela and Uruguay) (Uetz et al. 2017). The species inhabits natural anthropic impacted areas or urban centers (Vanzolini 1978, Baldo et al. 2008), being reported in some invasive Hemidactylus, the ability to displace native species (Hanley et al. 1998, Rivas Fuenmayor et al. 2005, Dame and Petren 2006).

The biogeographic pattern and colonization from Africa to the New world was study by Carranza and
Arnold (2006), which based on DNA sequences suggest the presence of H. mabouia in the new world at least 500 years ago. In Argentina, was reported for the first time by Williams (1988), from an urban area in Buenos Aires city, although misidentified as Hemidactylus turcicus (see Baldo et al. 2008). Later on, the presence of H. mabouia was described for Iguazu National Park, Misiones province (Genise and Montanelli 1991), and successive reports indicate the presence of this taxon in Chaco, Corrientes, and Formosa provinces (Federico and Cacivio 2000, Alvarez et al. 2002, 2009, Baldo et al. 2008).

\section{Methods}

Three juvenile specimens were collected during a field trip in austral spring 2017. The collected specimens were euthanized with Pentothal Sodium injection, fixed in 


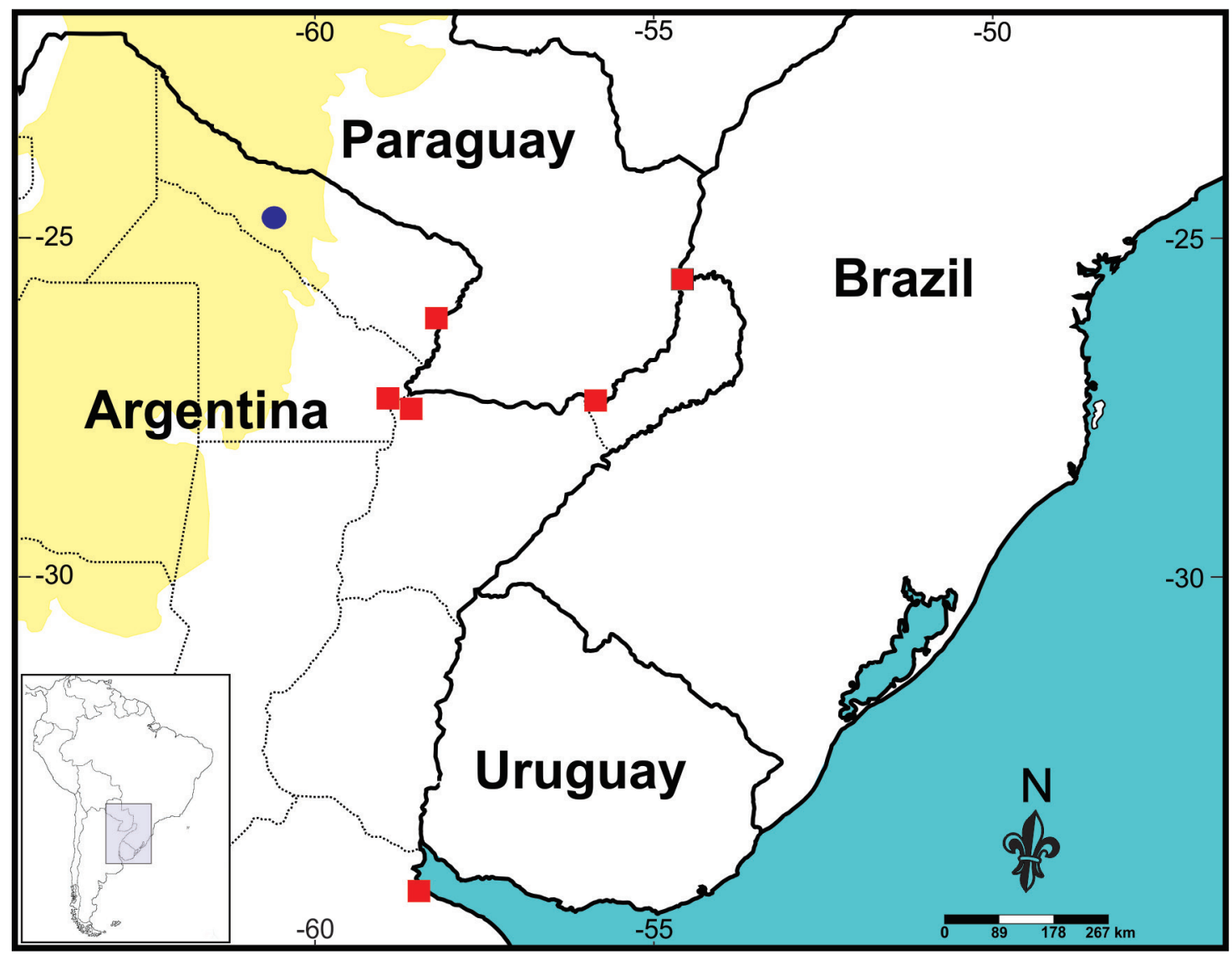

Figure 1. Distribution map of $H$. mabouia in Argentina. The blue solid circle indicates the new record. Red solid squares indicate previous records. The light yellow shaded area corresponds to the dry Chaco biogeographic region.

$10 \%$ formalin, and preserved in $70 \%$ alcohol. Voucher specimens have been deposited in the herpetological collection of the Laboratorio de Genetica Evolutiva (LGE), Instituto de Biología Subtropical (CONICET-UNaM), Posadas city, Misiones province, Argentina.

\section{Results}

\section{Hemidactylus mabouia (Moreau de Jonnès, 1818)}

New record. Argentina: Formosa Province, Patiño department: Las Lomitas city $\left(24^{\circ} 42^{\prime} 26^{\prime \prime}\right.$ S, 060 $35^{\prime} 40^{\prime \prime}$ W, WGS 84, 130 m a.s.1.), collected by D. Cardozo, P. Torres and O. Escalante on 29 September 2017 (3 juvenile specimens, LGE 20047-9) (Fig. 1).

Identification. Specimens were identified following Kluge (1969), Hoogmoed (1973) and Avila-Pires (1995) by the lamellae under the fourth toe, shape of the pupil, number of supralabial and infra labial scales (Fig. 2).

\section{Discussion}

The new report is the first record for the invasive species H. mabouia in the dry Chaco, a biogeographic region included in the Gran Chaco Sudamericano (Naumann 2006). The presence of $H$. mabouia in this region, which is characterized by the presence of multiple endemism (Szumik et al. 2012), represents a potential problem for conservation of fauna. As was previously mentioned, some Hemidactylus species share the ability of displacing native fauna (Hanley et al. 1998, Dame and Petren 2006, Rivas Fuenmayor et al. 2005), which suggests the need to carry out a greater survey of the fauna present in the dry Chaco and the potential threats to the conservation of the native fauna. This record extends the distribution range of H. mabouia by nearly 300 kilometers (in a straight line) from Formosa city, the nearest point previously reported (Alvarez et al. 2009).

\section{Acknowledgements}

DC thanks PICT 2014-1343 for financial support. Authors thanks to anonymous reviewers for improving the manuscript.

\section{Authors' Contributions}

All authors collected the data, made identifications, wrote the manuscript; and made the figures.

\section{References}

Alvarez BB, Aguirre RH, Céspedez JA, Hernando AB, Tedesco ME (2002) Atlas de Anfibios y Reptiles de las Provincias de Corrientes, Chaco y Formosa (Argentina) I. (Anuros, Cecílidos, Saurios, Amphisbénidos y Serpientes). Corrientes: Universidad Nacional del Nordeste. $156 \mathrm{p}$ 

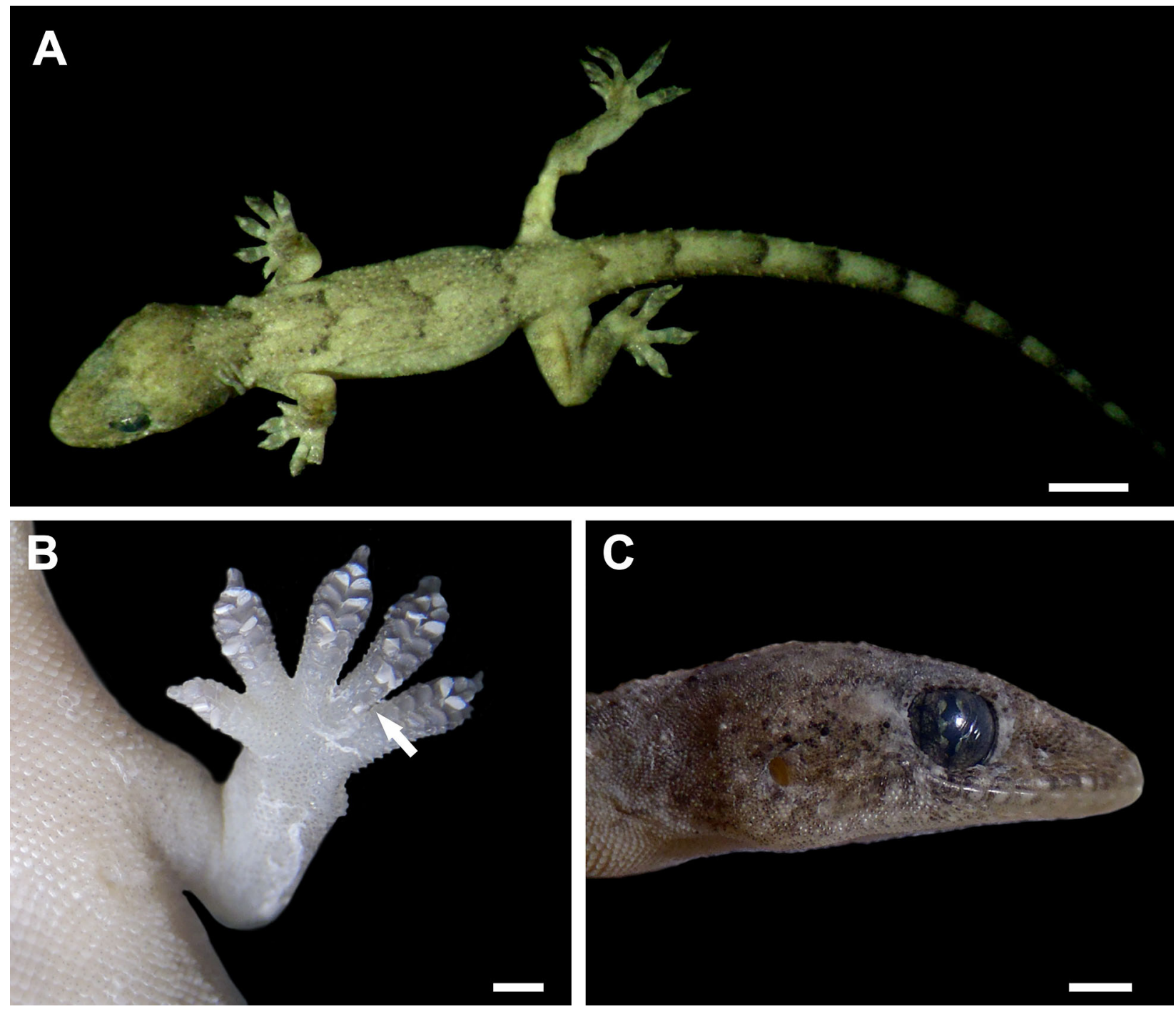

Figure 2. Specimens of H. mabouia LGE 20047. A. Dorsal view of the body. Scale bar $=5 \mathrm{~mm}$. B. Distance of the lamellae from the base of the foot. C. Lateral view of the head. Scale bar $=1 \mathrm{~mm}$.

Alvarez BB, Ruiz García A, Céspedez JA, Hernando A, Zaracho V Calamante C, Aguirre R (2009) Herpetofauna, provinces of Chaco and Formosa, Chaco Oriental region, north-eastern Argentina. Check List 5 (1): 074-082. http://doi.org/10.15560/5.1.74

Avila-Pires TCS (1995) Lizards of Brazilian Amazonia (Reptilia: Squamata). Zoologische Verhandelingen 299, Rijksmuseum van Natuurliike Historie, Leiden, The Netherlands, 706 pp.

Baldo D, Borteiro C, Brusquetti F, García JE, Prigioni C (2008). Reptilia, Gekkonidae, Hemidactylus mabouia, Tarentola mauritanica: distribution extension and anthropogenic dispersal. Check List 4 (4): 434-438. http://doi.org/10.15560/4.4.434

Carranza S, Arnold EN (2006) Systematics, biogeography, and evolution of Hemidactylus geckos (Reptilia: Gekkonidae) elucidated using mitochondrial DNA sequences. Molecular Phylogenetics and Evolution 38: 531-545. http://doi.org/10.1016/j.ympev.2005.07.012

Dame EA, Petren K (2006) Behavioural mechanisms of invasion and displacement in Pacific island geckos (Hemidactylus). Animal Behaviour 71: 1165-1173. http://doi.org/10.1016/j.anbehav.2005.10.009

Federico L, Cacivio PM (2000) Hemidactylus mabouia. Herpetological Review 31 (1): 53.

Genise JF, Montanelli SB (1991) Primer hallazgo de Hemidactylus mabouia (Moreau de Jones) en la Argentina. Boletín de la Asociación Herpetológica Argentina 7 (1): 23.

Hanley KA, Petren K, Case TJ (1998) An experimental investigation of the competitive displacement of a native gecko by an invading gecko: no role for parasites. Oecologia 115: 196-205. http://doi. org $/ 10.1007 / \mathrm{s} 004420050508$

Hoogmoed MS (1973) Notes on the herpetofauna of Surinam IV. The lizards and amphisbaenians of Surinam. Biogeographia 4: 419.

Hughes DF, Meshaka WE Jr, Van Buurt G (2015) The superior colonizing gecko Hemidactylus mabouia on Curaçao: conservation implications for the native gecko Phyllodactylus martini. Journal of Herpetology 49 (1): 60-63. http://doi.org/10.1670/13-16

Kluge AG (1969) The evolution and geographical origin of the New World Hemidactylus mabouia-brookii complex (Gekkonidae, Sauria). Miscellaneous Publications, Museum of Zoology, University of Michigan 138: 78.

Naumann M (2006) Atlas del Gran Chaco Sudamericano. Sociedad Alemana de Cooperación Técnica (GTZ), ErreGé \& Asoc. Buenos Aires, $92 \mathrm{pp}$.

Rivas Fuenmayor G, Ungueto GN, Bauer AM, Barros T, Manzanilla J (2005) Expansion and natural history of a successful colonizing gecko in Venezuela (Reptilia: Gekkonidae: Hemidactylus mabouia) and the discovery of $H$. frenatus in Venezuela. Herpetological Review 36 (2): 121-125.

Szumik C, Aagesen L, Casagranda D, Arzamendia V, Baldo D, Claps LE, Cuezzo F, Díaz Gómez JM, Di Giacomo A, Giraudo A, Goloboff P, Gramajo C, Kopuchian C, Kretzschmar S, 
Lizarralde M, Molina A, Mollerach M, Navarro F, Nomdedeu S, Panizza A, Pereyra VV, Sandoval M, Scrocchi G, Zuloaga FO (2012) Detecting areas of endemism with a taxonomically diverse data set: plants, mammals, reptiles, amphibians, birds, and insects from Argentina. Cladistics 28 (3): 317-329. http://doi. org/10.1111/j.1096- 0031.2011.00385.x

Uetz P, Freed P, Hošek J (Eds) (2017) The Reptile Database. http:// www.reptile-database.org. Accessed on: 2018-2-10.

Vanzolini PE (1978) On South American Hemidactylus (Sauria, Gekkonidae). Papéis Avulsos de Zoologia 31 (20): 307-343. 